\title{
Arkose sandstone - a forgotten treasure of Kwaczala
}

\author{
Piaskowce arkozowe - zapomniany skarb Kwaczały
}

\author{
Jacek Stanisz, Anna Ziobro \\ AGH University of Science and Technology, Faculty of Geology, \\ Geophysics and Environmental Protection, al. A. Mickiewicza 30, 30-059 Krakow \\ e-mail: jstanisz@agh.edu.pl,anna.ziobro@poczta.onet.pl
}
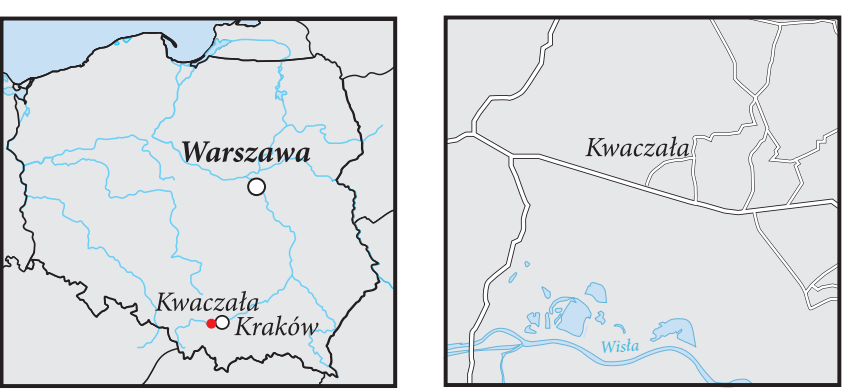

Abstract: In the surroundings of Krakow, there are few places where coarse carbonless rocks called the Kwaczała Arkose crop out. One of them is located near the Kwaczała countryside next to Alwernia. These deposits are unique in the scale of our country and Europe. They include silicified fragments of tree-trunks Dadoxylon. The current condition of gorges is presented in this paper. Many of them are uncared for, despite their significant scientific and educational value. An evaluation of the current outcrops' state was made. The authors also proposed how to develop the Kwaczała countryside. Key words: arkose, Kwaczała, araucaria

Treść: W okolicach Krakowa niewiele jest miejsc, gdzie odsłaniają się na powierzchni gruboziarniste osady karbońskie zwane arkoza kwaczalską. Jedno z nich znajduje się w pobliżu wsi Kwaczata obok Alwerni. Osady te sq ewenementem w skali naszego kraju i Europy. Zawieraja zsylifikowane fragmenty pni Dadoxylon. Aktualny stan wąwozów zostat przedstawiony $w$ niniejszym artykule. Wiele z nich jest zaniedbanych mimo znacznej wartości naukowej i edukacyjnej. Ocena stanu zawiera spis aktualnych wychodni. Autorzy przedstawili również propozycje rozwoju wsi Kwaczała.

Slowa kluczowe: arkoza, Kwaczała, araukaria

\section{Introduction}

The Kwaczała Arkose rocks, though quite well researched and described in the literature (Siedlecki, 1952a, 1952b; Turnau-Morawska, Łydka, 1954; Siedlecka, Krysowska, 1962; Pawlikowski, Holcer, 1994), are poorly displayed in the area. Unfairly, because they are interesting enough to make them available to people especially those, interested in expanding their geologic and geotouristic knowledge. These old Paleozoic sediments developed as Carboniferous gravels and sands containing silicified trunks of coniferous trees popularly called araucaria.

The purpose of this publication is to present the current state of knowledge about the Kwaczała Arkose and silicified trunks showing how huge the problem of the lack of protection and the little tourist land development in the surrounding of the Kwaczała village is.
In the 60's of last century, there already have been developed plans to preserve this area including the Gródek Gorge. Not only deposits and the modern flora (mosses, ferns), but also the morphology of the terrain (gorges) were the subject of protection. Unfortunately, works got stuck - there is still no agreement between the owners of sites including the gorges (current information from the Alwernia’s Municipal Office) (Alexandrowicz, Bogacz, 1971). An inventory carried out by the authors show how the number of outcrops was significantly reduced since the 60's of XX century. Buildings were located on many of them, others are overgrown. This causes blurring of sedimentary structures, while deposits are becoming less exposed. It's a great loss, because the area has significant tourist potential. Properly planned tourist routes, infrastructure and promotion of the region would benefit the local economy, and eventually start the entrepreneurship. This paper presents propositions of the land development. Especially tourism addressed to a particular recipient - in this case geologic, which becomes more popular not only in Poland but also in the world.

\section{Location of outcrops of the Kwaczala Arkose}

Outcrops of the Kwaczała Arkose occur in the Alwernia community in Chrzanów County. According to the physical and geographical division they are located on the Tenczyn Ridge, which is a part of Kraków - Częstochowa Upland (Kondracki, 2000).

The largest and best preserved outcrops of the Kwaczała Arkose are located near the Kwaczała village. Outcrops of these sediments can be also found in the vicinity of Poręba, Alwernia, Babice, Płaza, Zagórze and Chełmek. They occur mainly within the area located along the north bank of the Vistula River in the southern part of the Cracow region (Fig. 1) (Siedlecki, 1952b).

Gorges of the Kwaczała region, in which outcrops of arkose are preserved, cut the southern slope of the Tenczyn Ridge. The authors effectuated stocktaking and a valuation of existing outcrops in this area in the years 2010-2011.

The vast majority of gorges are covered by lush greenery, some of them by buildings, or by younger sediments. Outcrops of the Kwaczała Arkose are still well visible in: Gródek, Grabowiec and the Kozi Dół gorges.

Kozi Dół Gorge, which is located north-east from Kwaczała next to Karczusze displays V - shaped geomorphological form. 


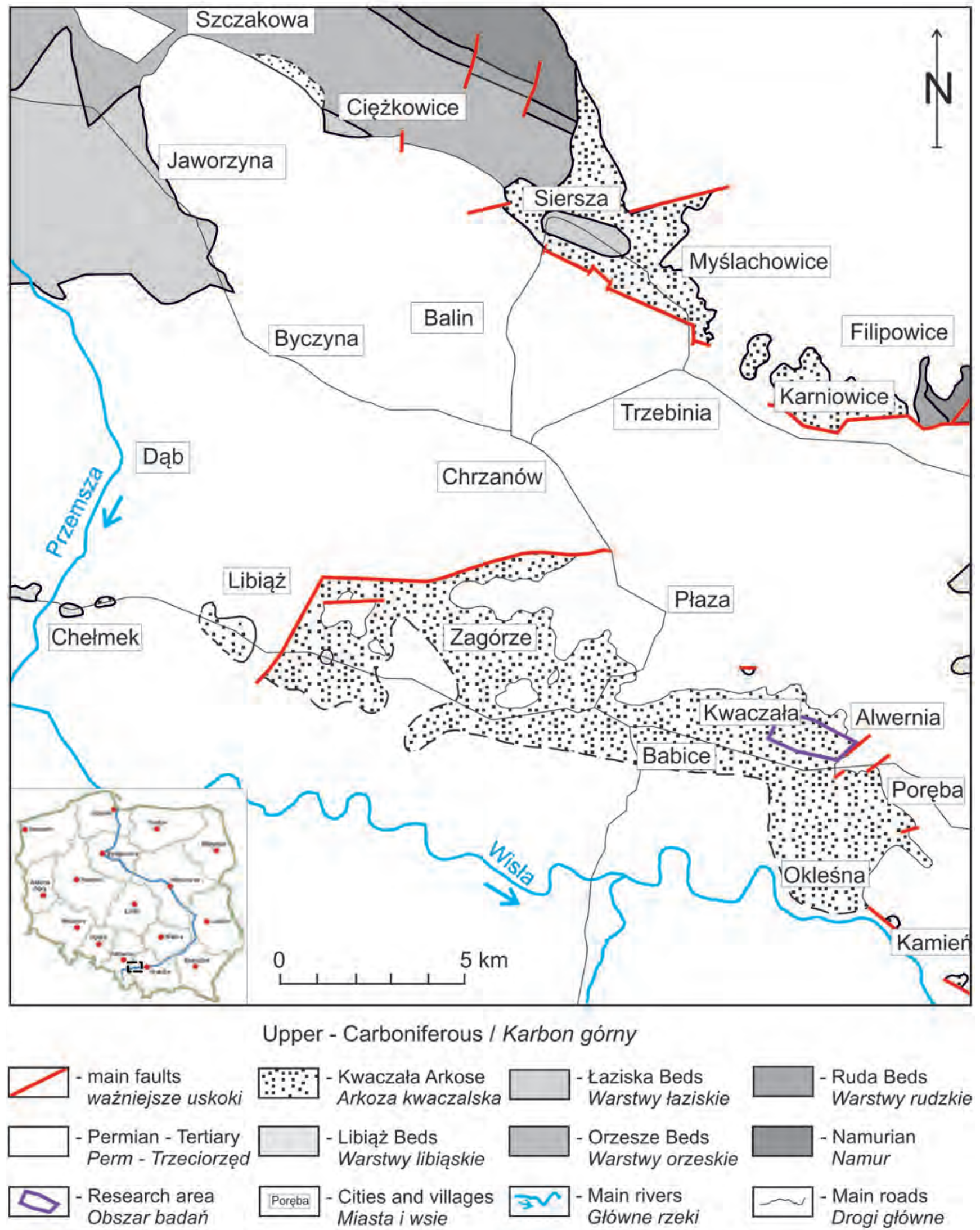

Fig. 1. Location of outcrops of the Kwaczała Arkose (Rutkowski, 1972) • Lokalizacja wychodni arkozy kwaczalskiej (Rutkowski, 1972)

Only one outcrop of the Kwaczała Arkose is located within this gorge. The rest of the slopes were covered by younger sediments and vegetation. This small outcrop has dimensions of about $1 \mathrm{~m}$ high and $2 \mathrm{~m}$ wide (Fig. 2). These sediments are white and grey hiatal slack arkose sandstone. 


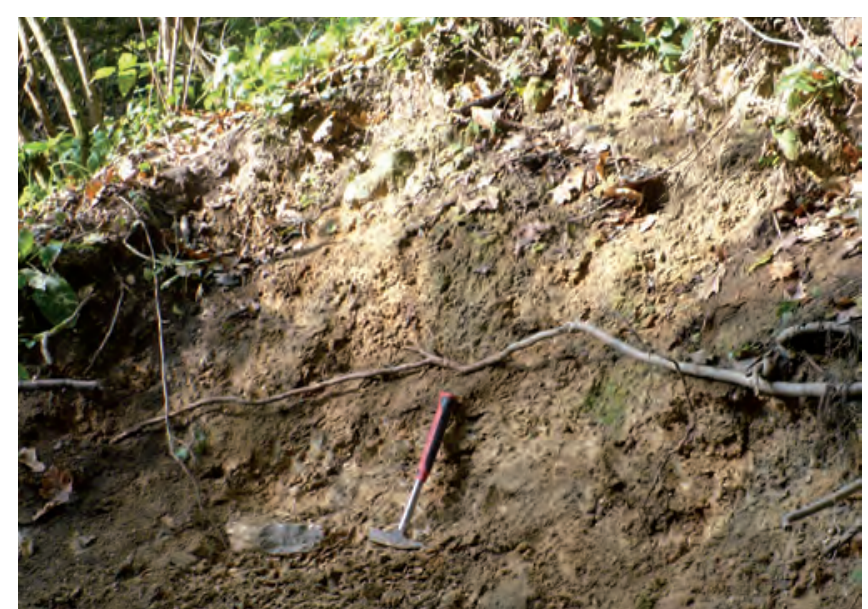

Fig. 2. The outcrop of the Kwaczała Arkose in the Kozi Dół Gorge, phot. A. Ziobro • Odsłonięcie arkozy kwaczalskiej w wąwozie Kozi Dół, fot. A. Ziobro

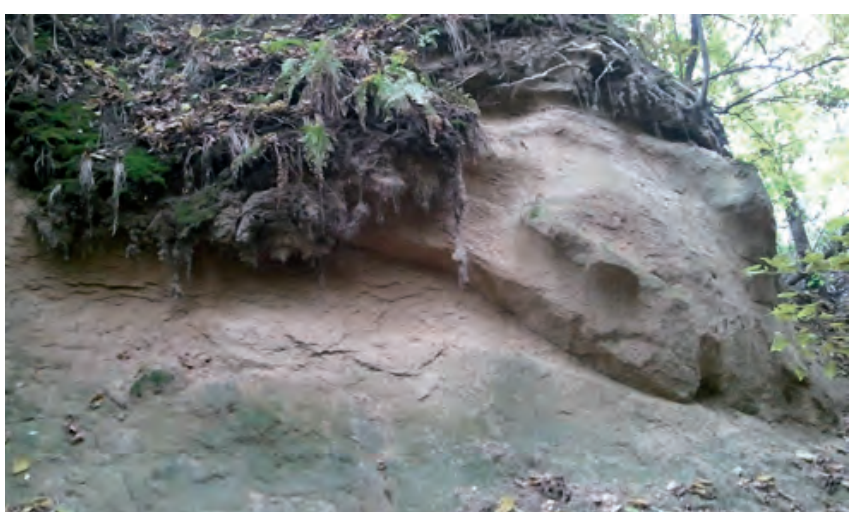

Fig. 3. The outcrop of arkose in the eastern slope of the Gródek Gorge, phot. A. Ziobro - Odsłonięcie arkozy kwaczalskiej we wschodnim zboczu wąwozu Gródek, fot. A. Ziobro

The largest, best known and, what is most important, the best preserved gorge - Gródek is located west of the Kozi Dół Gorge. It contains the most representative and still well preserved outcrops of the Kwaczała Arkose (Fig. 3-4). The gorge is about $0.5 \mathrm{~km}$ long, with a height of slopes up to $6 \mathrm{~m}$. The inventory of the nine outcrops was made by present the authors. The largest of them was about 8 meters high and 7 meters wide and was located in the west wall of about 250 meters from the entrance to the gorge (Fig. 5).

There are also three other outcrops located in the gorge, which is a branch of the Gródek at its entrance. Fine-grained and medium-grained arkose can be observed in these outcrops. Sandstones' colors are from gray - yellow to brownish - red. There are linear accumulations of different types of gravel stones and numerous clayey pebbles within the sandstones. Moreover, in one of the branches of Gródek gorge are also other interesting sediments - residual conglomerates are located.

Another important gorge, where the unique arkose sandstones deposits may be found is Grabowiec, which is the most western in relation to the Kwaczała village. The authors localized 12 outcrops in Grabowiec and one outcrop in the branching of the gorge. It is a small amount compared to the size of the gorge and the number of its branches. Most of the outcrops achieved significant sizes, which oscillate

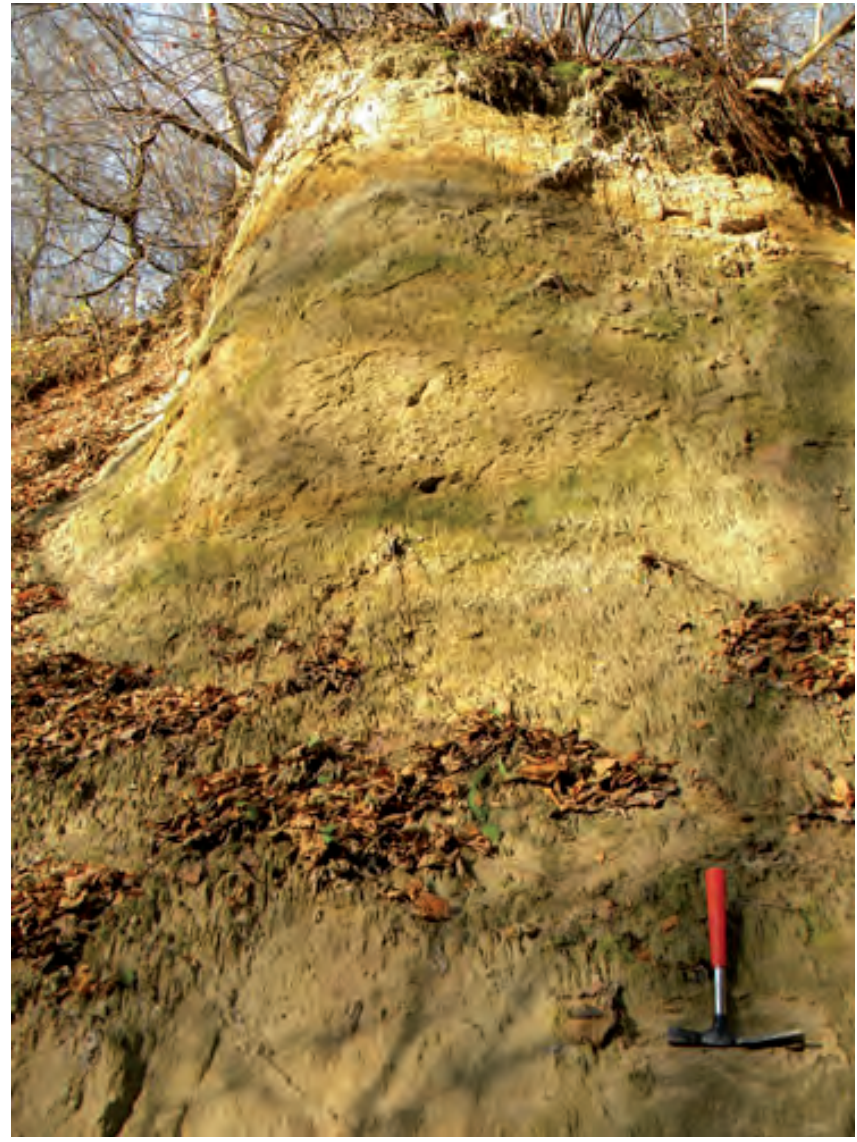

Fig. 4. One of the biggest outcrops of the Kwaczała Arkose in the western slope of the Gródek gorge, phot. J. Stanisz • Jedno z większych odsłonięć arkozy kwaczalskiej w zachodnim zboczu wąwozu Gródek, fot. J. Stanisz

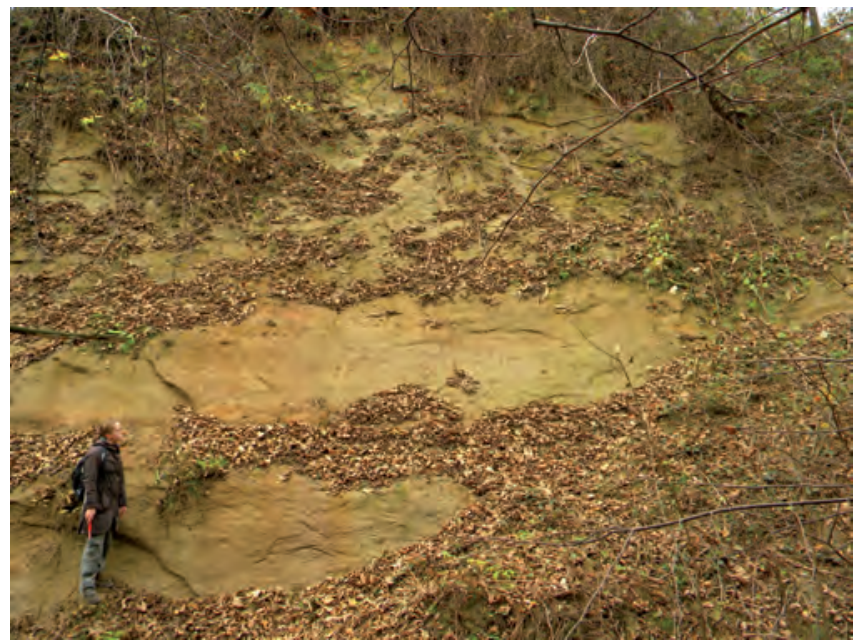

Fig. 5. The biggest outcrop of the Kwaczała Arkose located in the Gródek gorge, phot. J. Stanisz • Największe odsłonięcie arkozy kwaczalskiej zlokalizowane w wąwozie Gródek, fot. J. Stanisz

between up to $10 \mathrm{~m}$ in width and about 5-6 $\mathrm{m}$ in height, but they are already covered in many places by greenery (Fig. 6). The observed sediments are, as in Gródek gorge, mostly yellow and red fine-grained and medium-grained sandstones. Linear accumulations of gravel stones, which in some places formed specific layers up to $30 \mathrm{~cm}$ thickness are more frequent than in the case of Gródek gorge. 


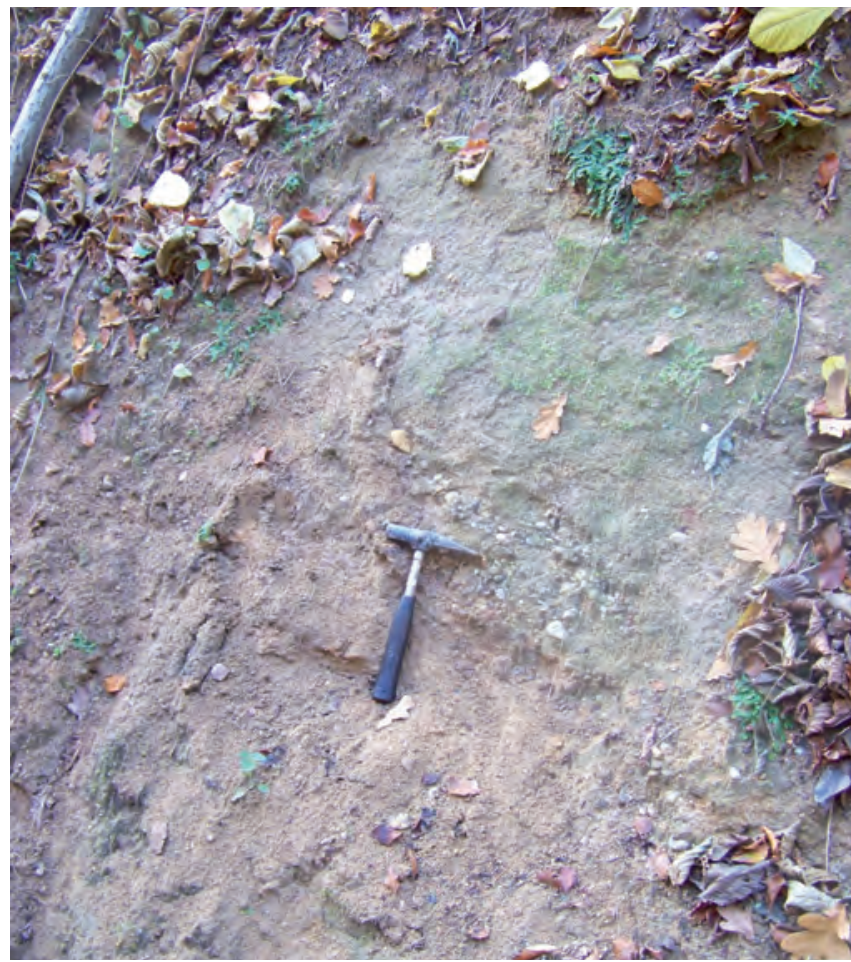

Fig. 6. The outcrop in the Grabowiec gorge, phot. A. Ziobro • Odsłonięcie w wąwozie Grabowiec, fot. A. Ziobro

The individual pieces of silicified wood were found in the bottom of the gorge lying under a thin layer of younger sediments probably left by water flowing during heavy rains.

In other gorges arkose sandstones' outcrops are absent. Figure 7 shows the location of inventoried outcrops.

\section{Lithological characteristics of the Kwaczala Arkose}

Sandstones with domination (over 25\%) of feldspar in skeleton's grains are labeled as arkose (arkose sandstones) (Czerny et al., 2008). The Kwaczała Arkose is lithologically differentiated sediment, mainly gritty, but in some places contains interstratified rocks - conglomerates and clays.

Sandstones from the arkose series were tested, allowing identification of a feldspathic material (Siedlecki, 1954; Turnau-Morawska, Łydka, 1954; Szuwarzyński, 2012). They contain mainly sharp-edges grains of quartz, whose content can be up to $61 \%$. Their size can reach from a few tenths of $\mathrm{mm}$ to several $\mathrm{mm}$. There are numerous fragments of potassium feldspars: orthoclase and microcline with sizes similar to quartz grains. Their content is generally higher than $25 \%$, which justifies the name of the sandstones as arkose ones (Siedlecka, Krysowska, 1962; Rutkowski, 1972). Granitoids and granites are their sources.

A frequent component of the Kwaczała Arkose is a kaolinite (up to $18 \%$ ), developed in the process of weathering of highly eroded feldspar's grains (Gradziński, 1972). In addition, arkose sandstones contain fragments of exotic rocks (gravel stones, which are described below), which could comprise up to $35 \%$ and micas (mainly muscovite) - up to $18 \%$, and in clayey parts mainly biotite (Rutkowski, 1972; Płonczyński, Łopusiński, 1993). There are also heavy minerals in arkose sandstones. Among them there are zircon, staurolite, tourmaline, rutile and fewer kyanite, garnet and apatite (Siedlecka, Krysowska, 1962).

The type of the binder is a matrix (rocks background) and is a mixture of calcium carbonate, sericite and iron compounds, which occur in different proportions.

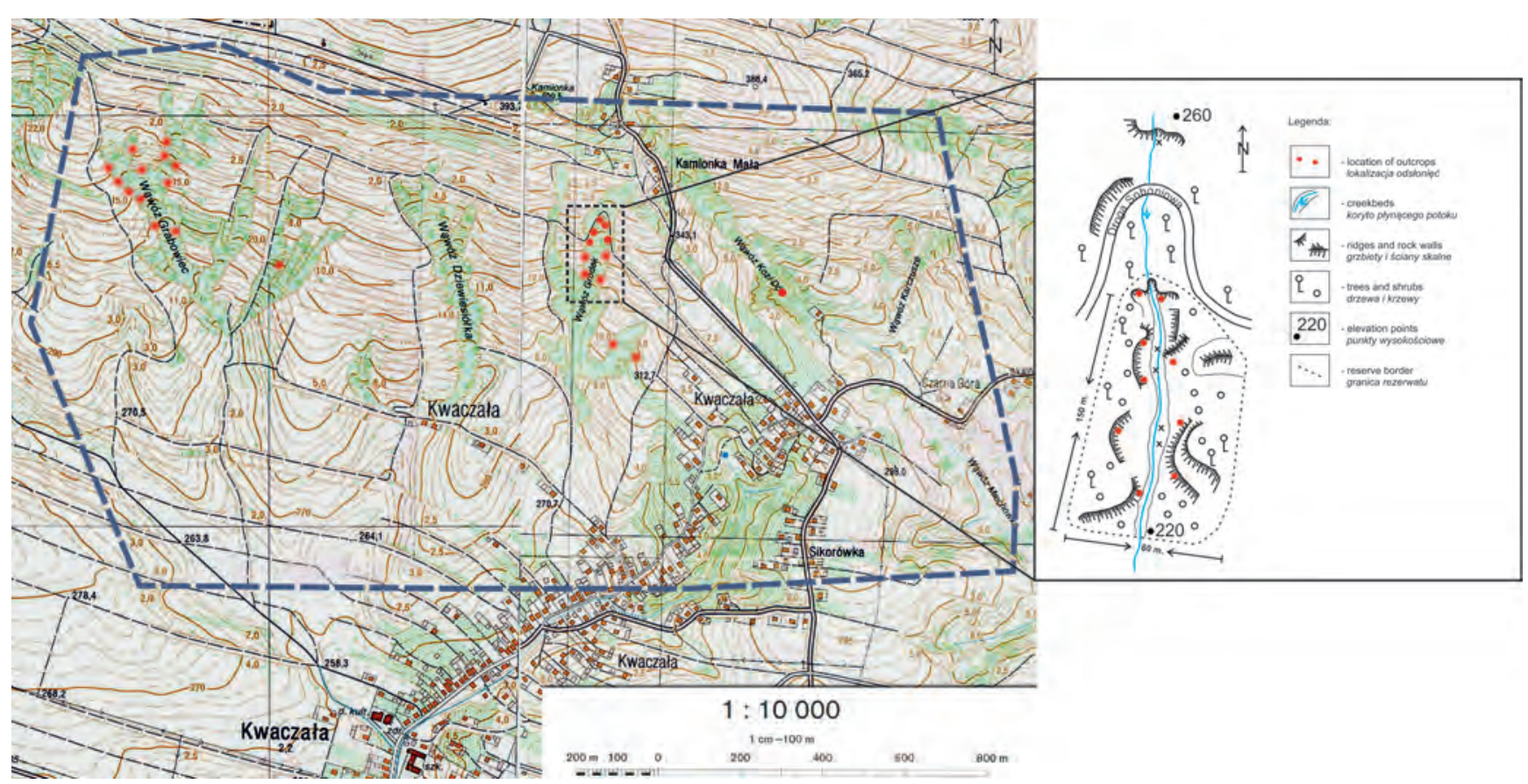

Fig. 7. Location of outcrops of arkose occurring in the surrounding of Kwaczała village (topographic map 1:10 000, sheet: Alwernia, Babice - modified), red dots - inventoried outcrops, purple dotted line - the area of research, black lines - the area and the plan of proposed in the 1960s Gródek reservation (Szuwarzyński, 2012) • Lokalizacja występujących w rejonie Kwaczały odsłonięć arkozy kwaczalskiej (mapa topograficzna 1:10 000, arkusze: Alwernia, Babice - zmodyfikowana); czerwone kropki - zinwentaryzowane odsłonięcia, fioletowa przerywana linia - obszar badań; czarne kreski - obszar oraz plan projektowanego w latach 60. XX wieku rezerwatu Gródek (Szuwarzyński, 2012) 
The participation of the binder in the volume of the rock ranges from $13 \%$ to $25 \%$. The material of these rocks is usually very poorly bonded and smoothed, and these sediments are rather loose, easily eroded. However, the increase in the content of iron and calcite typically translates into mildly stronger cementation of the sediments and its lower porosity. Sediments have very different colors from white through gray, pinkish, even to dark (Siedlecki, 1952b; Szuwarzyński, 2012) (Figure 8-10).

Gravel stones, which build conglomerates have different origination and are well smoothed. The arrangement of gravel stones' layers, whose thickness reach from over a dozen to tens of centimeters shows little lateral extent (Szuwarzyński, 2012). Among the gravel grains predominate quartz, but specimens of lidytes, eroded granites, granitic gneiss, quartz porphyries, orthoclase-biotite gneiss, eye gneiss, sericite-albite gneiss, quartzite with albite, quartz sandstones, conglomerates, limestone can be also be found (Pawlikowski, Holcer, 1994) (Fig. 11). It was found that they do not originate from the sediments surrounding the arkose. In all probability they were transported from the Caledonian-Variscan massifs covered by Carpathian nappes (Siedlecki, 1952b).

Relatively rare and irregular clay liners are pale reddish and purplish (Gradziński, 1972), sometimes with a greenish spots, which are the result of the processes of iron reduction. The thickness of the clayey parts range from a few centimeters up to several meters, but they often quickly declined, what precludes attempts of correlation. Sometimes they also generate forms called clay pebbles, irregularly arranged in the sandstones (Fig. 12). They are several centimeters, occasionally more than $30 \mathrm{~cm}$ in size (Siedlecki, 1952b). They have spherical or elliptical shapes, sometimes are a little bit elongated and take the pear-shaped form. Pebbles may also form thin layers.

Coarse parts of the Kwaczała Arkose do not have very clear and regular bedding. In places where it can be seen, banks have from $3 \mathrm{~m}$ to $5 \mathrm{~m}$. Fractional and diagonal stratification to an angle of twenty degrees north can be identified (Pawlikowski, Holcer, 1994). This last feature made determination of the direction from which the material was transported it possible. This direction was south and south - west, from the massif known in the literature as Pre-Carpathian (Rutkowski, 1972; Gradziński, 1972). The material origin was already discussed above (see also Szuwarzyński, 2012).

Fig. 8. White arkose with a piece of silicified tree trunk, phot. A. Ziobro - Arkoza o barwie białej z fragmentem skrzemieniałego pnia, fot. A. Ziobro

Fig. 9. White - yellow poorly sorted arkose, phot. A. Ziobro • Arkoza o barwie biało-żółtawej z bardzo wyraźnymi różnicami w wielkości ziaren, fot. A. Ziobro

Fig. 10. Arkose as poorly sorted red sandstone, phot. A. Ziobro • Arkoza w postaci słabo wysortowanego piaskowca o barwie czerwonawej, fot. A. Ziobro

Fig. 11. Gravel stones descended from arkose, phot. A. Ziobro • Otoczaki pochodzące z osadów arkozy kwaczalskiej, fot. A. Ziobro
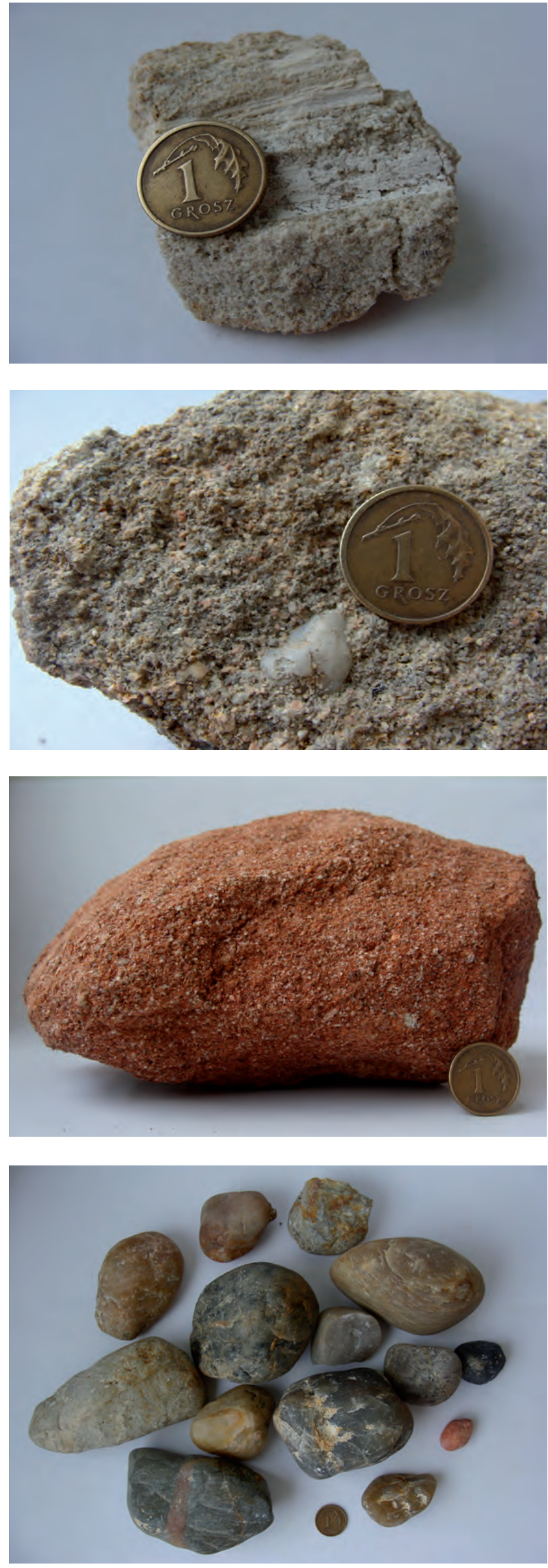
Arkose sandstones were formed in the terrigenous environment. Dry climate prevailing at that time was intertwined with rainy seasons during which there were heavy rains. Poorly sorted material was transported from the Pre-Carpathian Massif by periodic water of significant transport's force. Changeable sedimentation processes caused the differentiation of

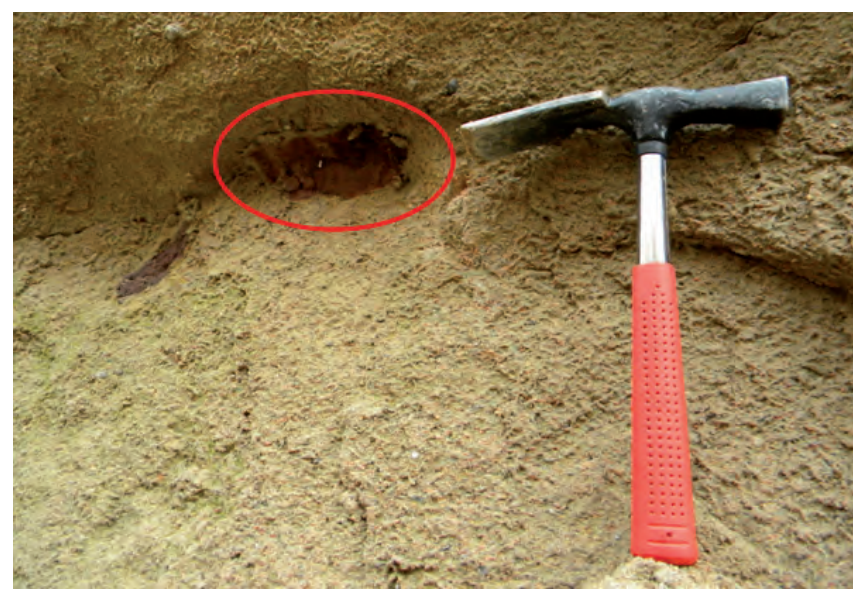

Fig. 12. Clayey pebble localized in arkose sediments, phot. A. Ziobro - Toczeniec ilasty zlokalizowany w osadzie arkozowym, fot. A. Ziobro

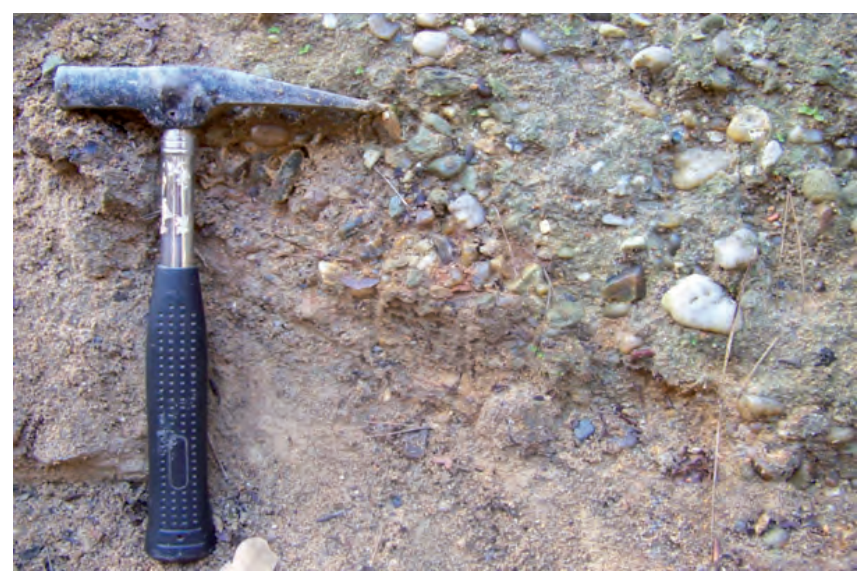

Fig. 13. The layer of gravel stones stuck in arkose sediments, phot. J. Stanisz • Warstwa otoczaków tkwiących w osadzie arkozowym, fot. J. Stanisz

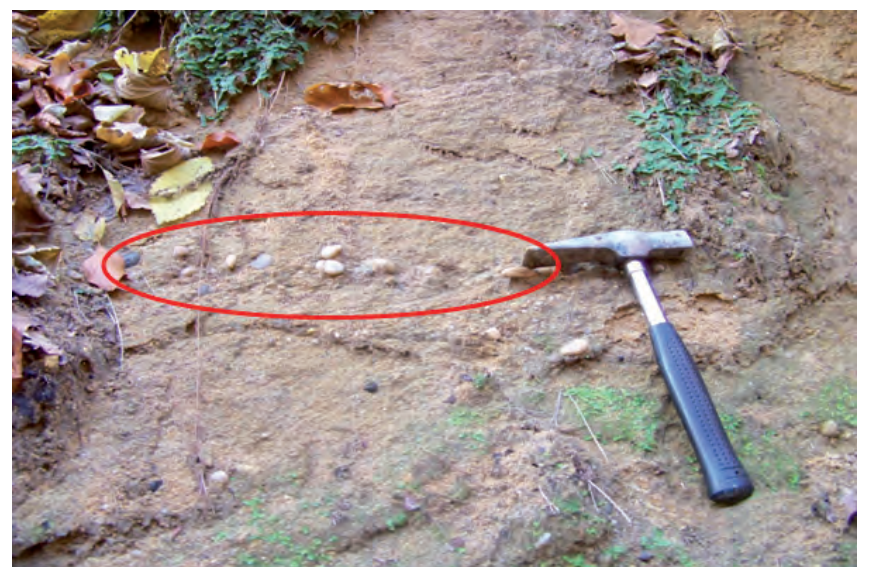

Fig. 14. Single layer of pebbles stuck in arkose sediments, phot. J. Stanisz • Pojedyncza warstewka otoczaków biegnąca w osadzie arkozowym, fot. J. Stanisz deposits. Then in dry periods, sediments deposited on the foreland of Pre-Carpathians were subjected to mechanical weathering, which were prevailing over the chemical one (Szuwarzyński, 2012). This led to douche and deflation processes, as a result of which a fine material has been removed and the thicker one created a thin cover (Rutkowski, 1972). It is often composed of gravel stones, which are dispersed in sandy sediment or occur in thin layers, in which they lie side by side and form linear accumulations of pebbles (Fig. 13) (Gradziński, 1972). Often only individually arranged fragments of rocks suggest lamination of the sediment (Fig. 14) (Siedlecki, 1952b). Clayey material within arkose sediments is probably a result of the periodic absence or significant reduction of the water's transport force and its stagnation in the local surface's pits (Rutkowski, 1972).

Characteristic and relatively rare sediments, which can be found in the western branch of the Gródek gorge, are residual conglomerates. They are the result of strong weathering processes. They consist mainly of quartz and arkose gravels, but there are also fragments of other rocks and silicified wood within it. The material is usually slightly dipped and sorted out. The binder of the rock is calcite, which in many places is coarsely crystalline and gives the rock a very characteristic appearance (Słomka et al., 2006) (Figs. 15, 16).

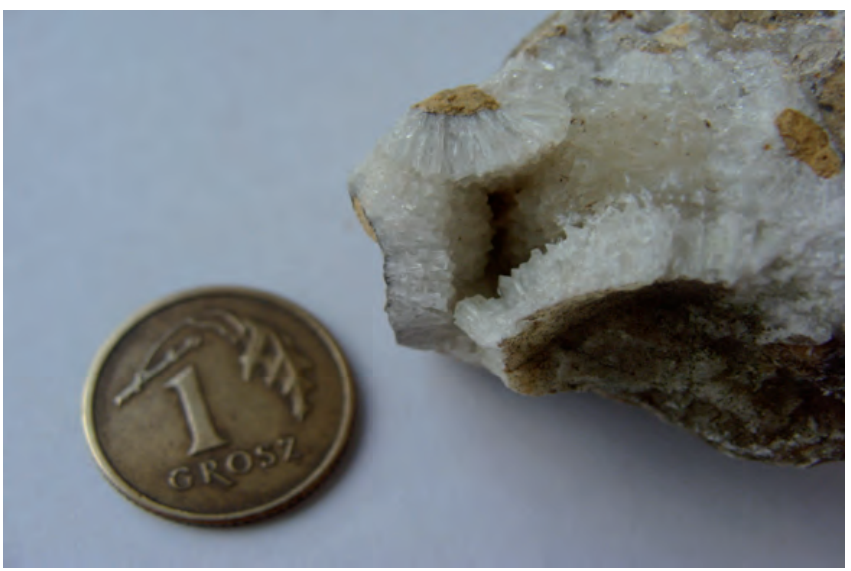

Fig. 15. Residual conglomerate with characteristic calcite binder, phot. A. Ziobro - Zlepieniec rezydualny z widocznym charakterystycznym spoiwem kalcytowym, fot. A. Ziobro

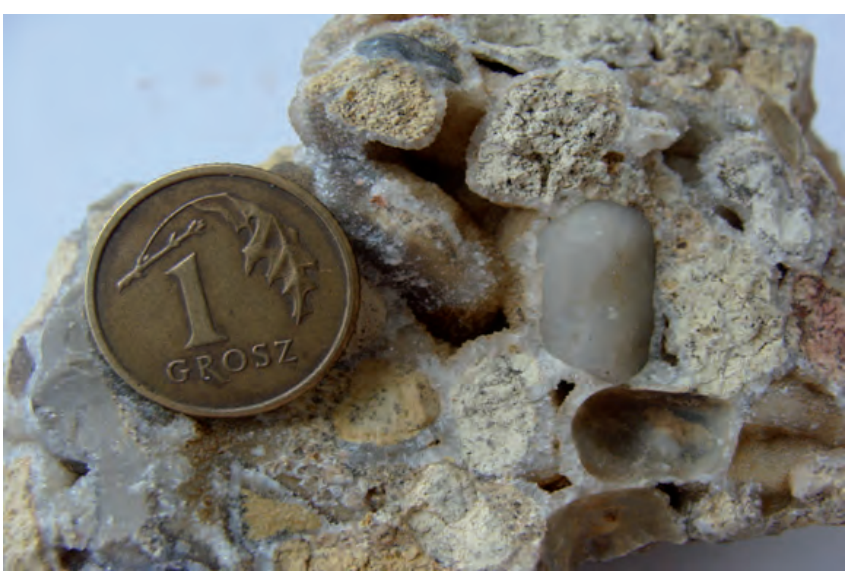

Fig. 16. Residual conglomerate with pebbles of different types of rocks, phot. A. Ziobro - Zlepieniec rezydualny z widocznymi otoczakami skał różnego typu, fot. A. Ziobro 


\section{Age of the Kwaczala Arkose}

Arkose sandstones and accompanying clays and conglomerates are labeled as the Kwaczała Arkose. Their age was determined as Stephanian (Late Carboniferous). Uniqueness of these deposits is connected with unproductivity, what means the lack of coal, from which this period in Poland is known (Rutkowski, 1972). The age of sediments was established by analogy to the arkose located in the Intra-Sudeten Basin, which displays similar lithology and the presence of silicified trunks of cordaites (early representatives of coniferous plants). Two different views on the age of the Kwaczała Arkose were formed over the years. The first one talks about arkose's formation earlier, at the end of the Westphalian - as the last phases of the productive Carboniferous sedimentation.
Moreover, the arkoses often are not marked out as separate Kwaczała Beds, but they are included to Libiąż Beds. According to Siedlecki (1952a, 1952b) arkose sediments near the Kwaczała village consistently lie discrepantly (lack of Stephanian sediments) on the productive formations of Westphalian (associated with coal-beds Libiąż, Chełm and Łaziska Beds) (Tab. 1).

The second, slightly different view argues for continuity of sedimentation of Westphalian (Libiąż Beds) and Stephanian deposits (the Kwaczała Arkose). Westphalian deposits differ from the Stephanian ones by overtone of clayey layers (Stephanian are spotted) and the presence of coal seams (in Westphalian). These conclusions were supported by the research results of the Płaza 203 core in the 60’s XX (Rutkowski, 1972; Szuwarzyński, 2012).

Tab. 1. Scheme of the stratigraphy of Stephanian and Permian sediments of the Cracow area (Siedlecki, 1952a, 1956) • Schemat stratygrafii utworów stefanu i permu obszaru krakowskiego (Siedlecki, 1952a, 1956)

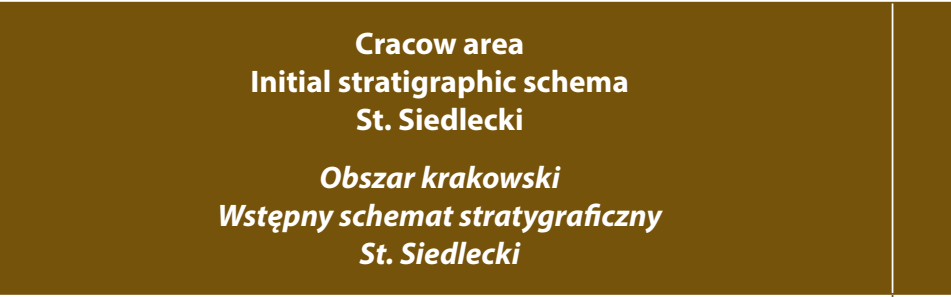

\section{Orogenic phases \\ (Stille's 1924, 1928) and volcanism \\ Fazy górotwórcze \\ (wg Stillego 1924, 1928) \\ i wulkanizm}

\begin{tabular}{|c|c|c|}
\hline \multirow{3}{*}{ 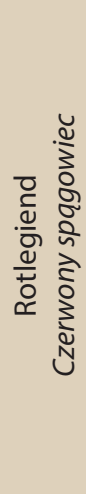 } & $\begin{array}{c}\text { Filipowice tuffs with layers } \\
\text { of Myślachowice conglomerates in its bottom part. Melaphyre } \\
\text { (Rudno, Regulice, Poręba) and porphyry (Miękinia) } \\
\text { Tufy filipowickie w spagowej części przeławicone ze zlepieńcami } \\
\text { myślachowickimi. Wylewy melafirów (Rudno, Regulice, Poręba itd.) } \\
\text { oraz porfirów (Miękinia) }\end{array}$ & \multirow{3}{*}{$\begin{array}{l}\text { Saalska phase } \\
\text { Strong development of Myślachowice } \\
\text { conglomerates and volcanic eruptions } \\
\text { Faza saalska } \\
\text { Zaznaczona silnym rozwojem zlepieńców } \\
\text { myślachowickich i erupcjami wulkanicznymi }\end{array}$} \\
\hline & $\begin{array}{c}\text { Myślachowice conglomerates, sandstones and red clay with } \\
\text { gypsum and salt (Głazówka, Sławków) }\end{array}$ & \\
\hline & $\begin{array}{l}\text { Zlepieńce myślachowickie } \\
\text { i odpowiadające im piaskowce oraz czerwone gliny z gipsem i z sola } \\
\text { (Głazówka, Sławków) }\end{array}$ & \\
\hline \multirow{3}{*}{ 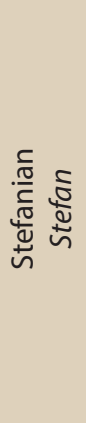 } & $\begin{array}{c}\text { Myślachowice conglomerates and tuffs (Karniowice) } \\
\text { Karniowice Travertine } \\
\text { Karniowice Sandstones }\end{array}$ & \multirow{3}{*}{-} \\
\hline & $\begin{array}{c}\text { Zlepieńce myślachowickie i tufy (okolice Karniowic) } \\
\text { Martwica karniowicka } \\
\text { Piaskowce karniowickie }\end{array}$ & \\
\hline & $\begin{array}{l}\text { Kwaczała Arkose with Araucarites and red clays } \\
\text { Arkoza kwaczalska z Araucarites } \\
\text { i odpowiadające jej czerwone iły }\end{array}$ & \\
\hline \multirow[b]{2}{*}{ 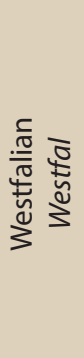 } & $\begin{array}{l}\text { UNCONFORMITY } \\
\text { NIEZGODNOŚĆ }\end{array}$ & \multirow{2}{*}{$\begin{array}{c}\text { Asturian phase } \\
\text { Diabase's intrusions } \\
\text { (Niedźwiedzia Góra, Zalas III, W-kie Grogi) } \\
\text { Faza asturyjska } \\
\text { Intruzje diabazów (Niedźwiedzia Góra, Zalas III, } \\
\text { Wielkie Grogi) }\end{array}$} \\
\hline & $\begin{array}{c}\text { Productive Carboniferous } \\
\text { (Libiąż, Chełm, Łaziska and Orzesze Beds - Filipowice and } \\
\text { Sławkowa) } \\
\text { Karbon produktywny } \\
\text { (warstwy libiąskie, chełmskie, łaziskie, orzeskie - w okolicach Filipowic } \\
\text { i Sławkowa także warstwy grupy brzeżnej) }\end{array}$ & \\
\hline
\end{tabular}


The Arkose sediments thickness exceed often $100 \mathrm{~m}$, but never $150 \mathrm{~m}$. They usually lie horizontally only in the central part of the area of their occurrence (around Zagórze), showing about $2^{\circ}-5^{\circ}$ inclination towards the north and north-east (Siedlecki, 1952b). The Westphalian sediments have larger angles of inclination, and it is a cause of incompatibility. It is believed that it is the result of Asturian orogenic phase which caused the tectonic deformations of older layers, but not arkose sediments. The Paleozoic are covered mainly by Tertiary and Quaternary sediments, sometimes also by Triassic sandstones and claystones (Siedlecki, 1952a, 1952b) as well as mentioned by Siedlecki (1956) Karniowice Travertine and Karniowice Sandstones (Fig. 17), Myślachowice Conglomerates and tuffs (mostly associated with Early Permian) occurring in the surroundings of Karniowice. Dżułyński (1956) distinguished a sandy Lower Jurassic series, which lies directly on the arkose sediments in a natural outcrop located on the Dzierwińska Mount (surroundings of Kamień, over the Vistula River, 10 km south-east of Kwaczała).

The typical element in arkose sediments are silicified tree trunks, which are the only group of organic remains preserved. The largest and the most significant appearances of them are located in the Intrasudetic Basin (mainly area of Nowa Ruda), the Roztocze and around Chrzanów (Szuwarzyński, 2012). All these fossils are silicified tree trunks in sandstones and conglomerates, to the majority of which the terrigenous origin is ascribed. There is no possibility to define clear boundaries of araucaria occurrence in sediments. It is mainly caused by the lack of arkose outcrops at most of the studied areas. They are usually covered by younger sediments. Moreover, fragments of silicified trunks also do not show any regularity of arrangements in the arkose (Szuwarzyński, 2012). Tree trunks occurred in the
Kwaczała Arkose sediments, have very different sizes, up to $7.5 \mathrm{~m}$ length and up to $1.2 \mathrm{~m}$ thickness (Rutkowski, 1972).

There is a problem with nomenclature of those silicified tree trunks in the Kwaczała Arkose because of the great number of terms in use even though all of them relate to the same type of wood. In the past, they have been attributed to the primal types of coniferous plants - Araucarites (Rutkowski, 1972) and today to the type of Dadoxylon (D. schrollianum Goeppert, D. rollei Unger, D. saxonicum Goeppert) (Zastawniak, 2001). That term was created to describe fragments of petrified wood discovered in Upper Carboniferous sediments in Scotland in 1847. It is typically used for Paleozoic silicified wood and refers to a specific part of the plants. This part is the trunk, which is built of a specific tissue - a timber of tubes separated from each other with a small amount of parenchyma cells. Construction like this is currently observed in large-leaved gymnospermum plants (Reymanówna, 1962; Kotasowa, 1968; Pacyna, 2012).

At the same time, in many cases authors of the terms did not adduce detailed criteria, which could allow to differ new types of wood from that ones, which have already been characterized. The latest studies show, that the wood found in the Kwaczała Arkose do not resemble Dadoxylon. It is indicated by their size and lack of stroma with the characteristic lenticular air vacuums. Dadoxylon is currently combined with wood of cordaites (fossil gymnosperms plants). A slender trunk and extended tree-tops were characteristic for Cordaitinae class. Their leaves were inflexible, embedded spirally around the trunk with a wide stroma (Kotasowa, 1968). Cordaites could attain up to 50 meters in height. In turn the early conifers, which are considered to be the blank material for the fossilized tree trunks in the vicinity of Chrzanów, had relatively small sizes (Pacyna, 2012).

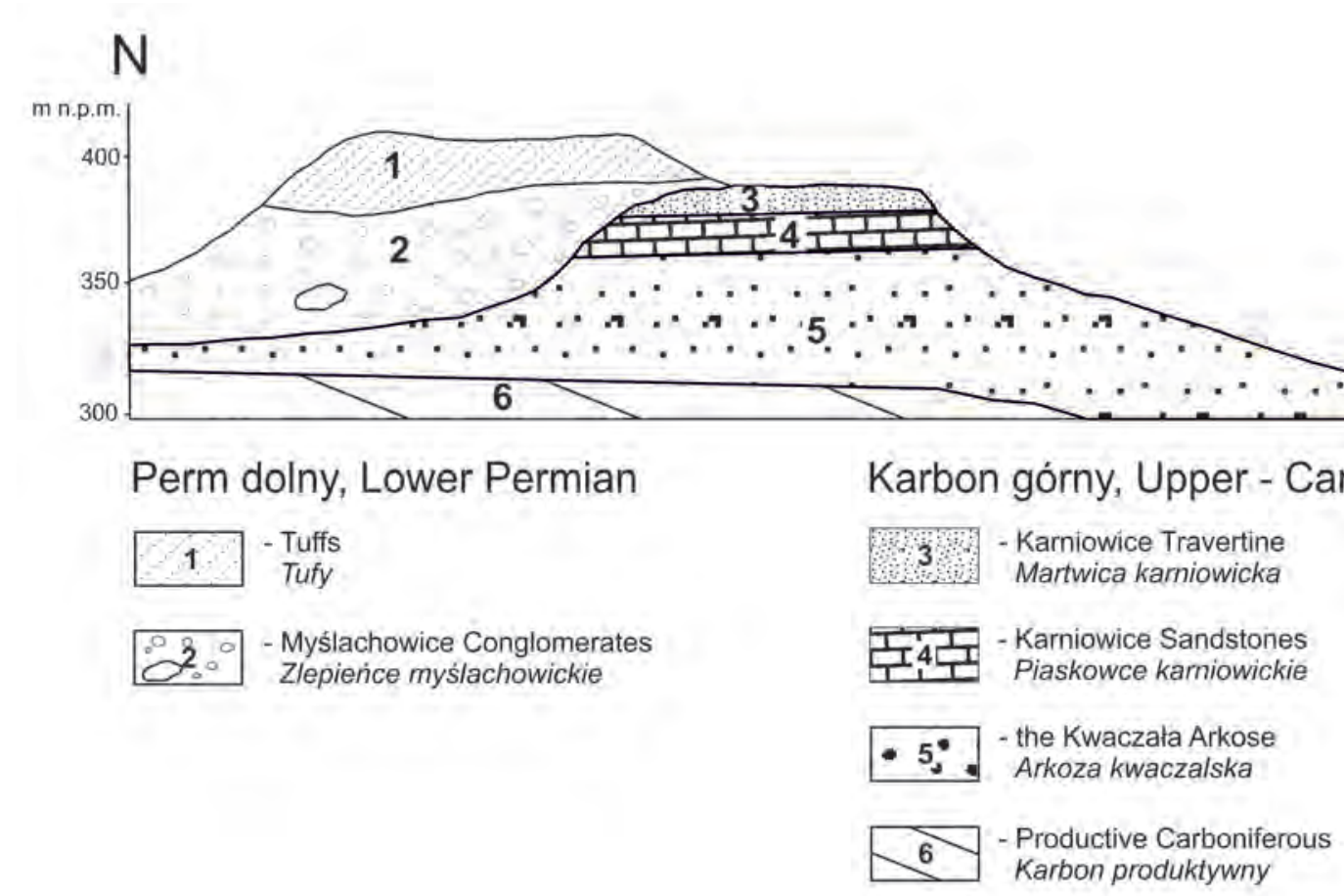

Fig. 17. The profile of stratification arkose sediments against adjoining layers (Siedlecki, 1952b) • Profil ułożenia osadów arkozowych względem warstw sąsiednich (Siedlecki, 1952b) 


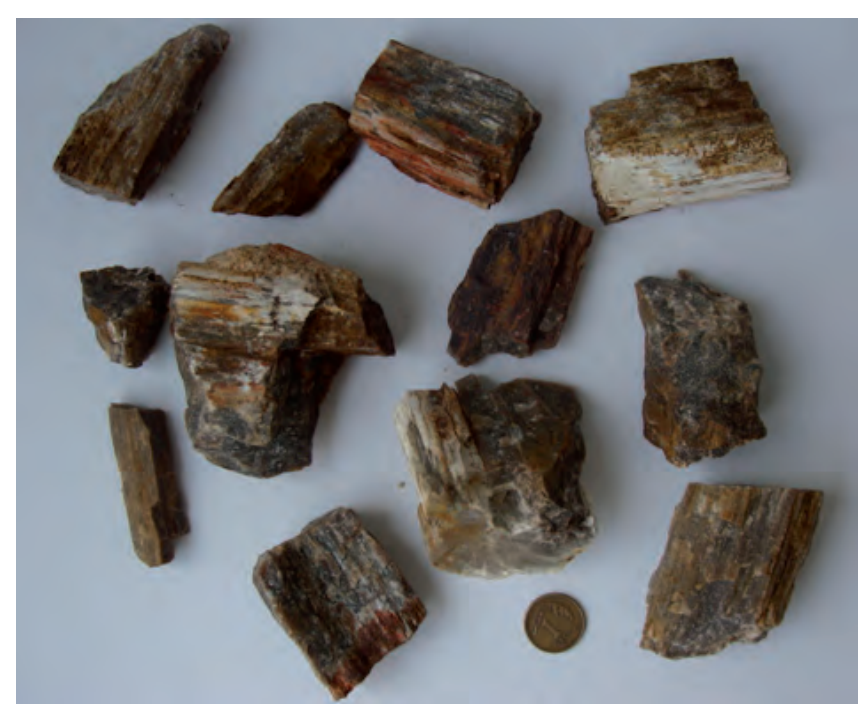

Fig. 18. Fragments of silicified tree trunks with different colors, phot. A. Ziobro • Fragmenty skrzemieniałych pni o wyraźnie różnorodnych barwach, fot. A. Ziobro

Fragments of the tree trunks were silicified after sedimentation and they lie slightly flattened (axis ratio of vertical to horizontal is 0.8-0.9) in situ in the sediment (on site) in an east-west direction (deviation of about 20-30) (Pawlikowski, Holcer, 1994). They were placed in the sediments with the material washed by massive floods generated in times of rain. The lack of branches, roots and crust suggests the tree trunks were transported (in unaffected forms) from distant areas. The lack of those fragments could be also a result of sharp-edge grains transported in a suspension. They had to come from the areas, which had a more humid climate, what allows the development of those plants. Arkose sediments were deposited in the definitely warmer and drier climate (Szuwarzyński, 2012).

Trunks have different colors (Fig. 18) from black by pinkish to white, but usually they are brownish and dark brown (Fig. 19). Fragments of the trunks and its surroundings can be shared into several zones. A detailed description of them was presented by Pawlikowski and Holcer (1994). In turn

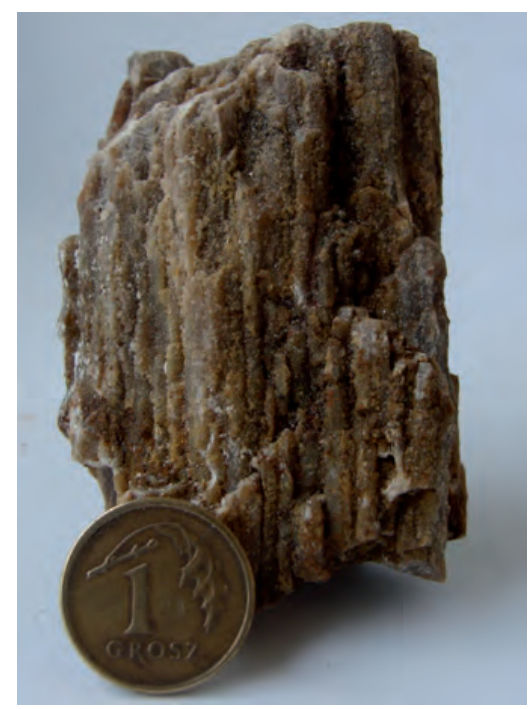

Fig. 19. Fragment of brown silicified tree trunk, phot. J. Stanisz • Fragment skrzemieniałego pnia o barwie brunatnej, fot. J. Stanisz other researchers have discussed the structural and textural characteristics of silicified fragments of tree trunks (Turnau-Morawska, Łydka, 1954; Szuwarzyński, 2012).

A source for silicification of wood was silica's plethora. Today, around Babice (on the Lipowiec Hill) similar processes were observed near mouldered beech's trunk. As in the case of araucaria, around the tree trunk reddish (rich in oxides of Fe) and creamy zones are observed (rich in clay minerals) (Pawlikowski, Holcer, 1994).

\section{Evaluation of the outcrops' conservation state and land development in gorges in Kwaczala}

The area of occurrence of the Kwaczała Arkose around Chrzanów with silicified fragments of Dadoxylon's trunks has not been enclosed with a special protection. So far only the documentation site in the Gródek Gorge was created (Alexandrowicz, Bogacz, 1971). More strict protection could save the outcrops of these unique deposits from destruction. It does not mean that attempts were not drawn out. Specific projects of a reservation in Gródek gorge in Kwaczała were made by Marian Kuc (1959) (Fig. 7). It could protect not only the sandstone's outcrops and silicified tree trunks, but also entered the mosses (Gyroweisia tennis) and ferns (Polystichum aculeatum) found in gorges as well as the gorges morphology (Szuwarzyński, 2012).

The gorges in Kwaczała village (especially Gródek, which is rich in arkose's outcrops), have a considerable scientific and tourist value. This gorge appeared on the list of 100 geotourist objects in Poland and in the Polish Geosites Central Register (documentary post - card made by Joniec in 2005). Currently gorges in Kwaczała are located within Tenczyn Landscape’s Park (Szuwarzyński, 2012).

Some gorges in Kwaczała can be reached by paths leading directly from the provincial road number 780, which runs through the village. The lack of signs indicating the direction to the gorges describing their geomorphology and geology is the great impediment. The only source of information is an imprecise map (Fig. 20) and plaque - pointer.

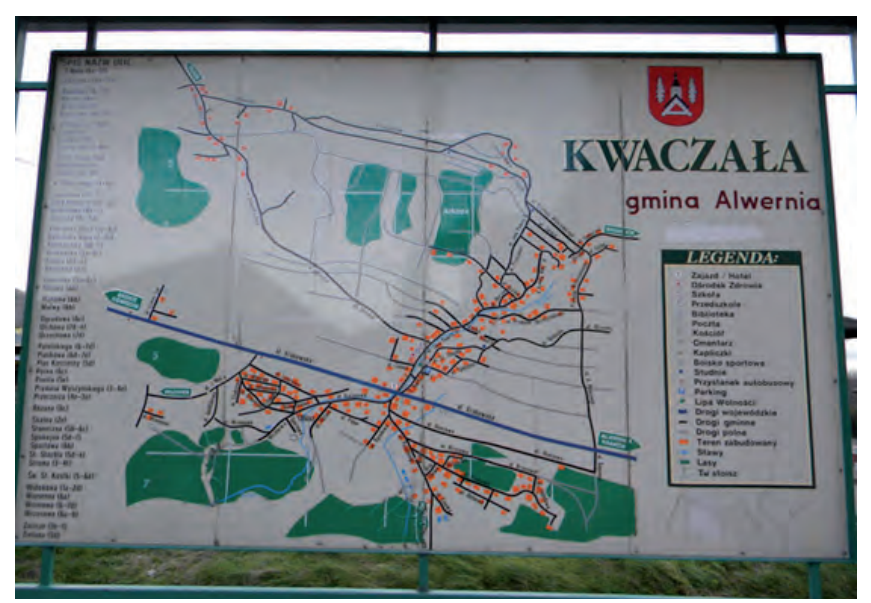

Fig. 20. Information board in the Kwaczała village, which shows very general occurrence of the kwaczała arkose sediments, phot. A. Ziobro - Tablica informacyjna we wsi Kwaczała ukazująca bardzo ogólne występowanie osadów arkozy kwaczalskiej, fot. A. Ziobro 


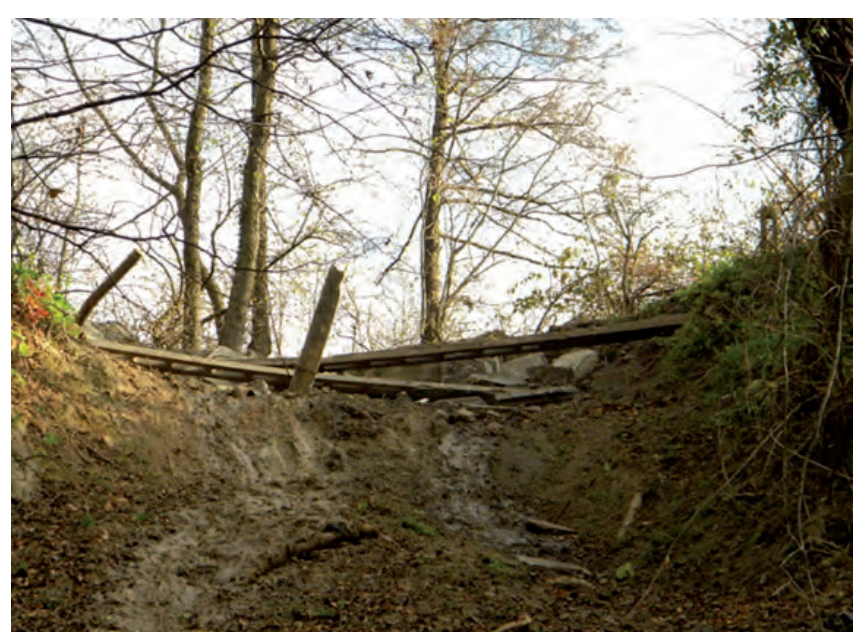

Fig. 21. Landslide in the Gródek gorge, phot. J. Stanisz • Zsuw ziemi w wąwozie Gródek, fot. J. Stanisz

As it was described earlier, both the land development of outcrops in gorges in Kwaczała, as well as the level of information about these sediments and their uniqueness is very wan. They are inaccurate and in some places do not even exist. In this situation it would be a great idea to create information boards about geomorphology and geology of this area. The most important issue is to create clear and understandable geological information for people. Moreover, cleaning the area up and setting the tables would make gorges significantly more nice-looking. A great way to attract visitors would be also building a viewing platform on one of the slopes of the gorge, for example in Gródek. Unhappily there is a problem with slipping down ground, which must be solved during land development (Fig. 21). One of the possible solutions could be a well-designed drainage near the walls, which are the most vulnerable on geodynamic deformations.

To improve the tourist and information infrastructure some promotional works should be organized. Keys are gorges
Gródek and Grabowiec. Outcrops of significant sizes are suitable for exposure. Besides signage, it is necessary to mark out the track to the gorges, and within them, with the possibility of continuation to the Simota Gorge. It could be a great geotourist offer. As an addition to those activities, an interesting idea would be also printing and publishing brochures, which could complete information provided on the plaques.

\section{Summary}

Due to the presence in the area unique and rare outcrops of arkose Kwaczała - carbon-free Carboniferous sediments with silicified fragments of Dadoxylon's trunks, Kwaczała has a unique geologic and tourist potential. In the course of the authors' works there were several significant outcrops in gorges (Gródek and Grabowiec) localized west of the Kwaczała village. A few of the arkose's outcrops made them unique. They still are covered by younger sediments and overgrowing.

The condition of the outcrops is poor but there is still a huge possibility to save these exceptional sediments from destruction. To aim this, action to protect these positions and to promote this geologic valuable element should be taken. Certainly this would increase the tourist attractiveness of Kwaczała. It can be achieved by tapping the proposals put forward in this article.

Fragmented agriculture with small farms dominates in this area, what is typical for the Małopolska Province, and the industry is not well developed. The development of geotourism is in fact a great opportunity for progress for this region, providing possibility of earnings and workplaces for the local community. In this case, an abiotic object could be a catalyst for the growth of inhabitants' entrepreneurship. It should be remembered, that it would have to be regulated by law, because there is a great concern about the possibility of devastation and complete destruction of these geological objects.

\section{Streszczenie}

\section{Piaskowce arkozowe - zapomniany skarb Kwaczały}

\section{Jacek Stanisz, Anna Ziobro}

\section{Wprowadzenie}

Osady arkozy kwaczalskiej wykształcone są jako osady paleozoiczne (żwiry i piaski stefanu) i zawierają zsylifikowane pnie drzew iglastych potocznie zwane araukariami (Rutkowski, 1972). Choć dość dobrze zbadane i opisane w literaturze (Siedlecki, 1952a, 1952b; Turnau-Morawska, Łydka, 1954; Siedlecka, Krysowska, 1962; Pawlikowski, Holcer, 1994), są one słabo wyeksponowane w terenie.

\section{Lokalizacja odsłonięć arkozy kwaczalskiej}

Występowanie odsłonięć utworów arkozowych związane jest głównie z obszarem położonym wzdłuż północnego brzegu Wisły: Poręba, Alwernia, Babice, Płaza, Zagórze i Chełmek (Fig. 1) (Siedlecki, 1952b). Największe i najlepiej zachowane wychodnie znajdują się w pobliżu wsi Kwaczała (Wyżyna Krakowsko-Częstochowska, okolice Alwerni). Odsłonięcia arkozy w tym rejonie dobrze zachowane są jeszcze w wąwozach: Kozi Dół (Fig. 2), Gródek (Fig. 3-5) i Grabowiec (Fig. 6). Pozostałe wąwozy: Miechówka, Karczusze oraz Dziewiesiółka porośnięte są obecnie roślinnością, zabudowane lub przykryte młodszymi osadami. Dowiodły tego prace inwetaryzacyjne przeprowadzone w latach 2010-2011 w rejonie wsi Kwaczała (Fig. 7).

\section{Charakterystyka litologiczna arkozy kwaczalskiej}

Piaskowce arkozowe (arkoza kwaczalska) zawierają w swoim składzie przede wszystkim ostrokrawędziste ziarna kwarcu (do 61\%). Ponadto liczne są okruchy skaleni potasowych, ortoklazy i mikrokliny (Siedlecka, Krysowska, 1962; Rutkowski, 1972).

Częstym składnikiem arkozy kwaczalskiej jest kaolinit (do 18\%) powstały z przeobrażenia silnie zwietrzałych ziarn skaleni (Gradziński, 1972). W jej składzie znajdują się 
też okruchy skał obcych (otoczaków), które stanowić mogą nawet 35\% oraz łyszczyki (głównie muskowit) - do 18\%. W częściach ilastych dominuje biotyt (Rutkowski, 1972; Płonczyński, Łopusiński, 1993). Obecne są również w arkozie minerały ciężkie. Wśród nich: cyrkon, staurolit, turmalin, rutyl, a w mniejszych ilościach: cyjanit, granat, apatyt (Siedlecka, Krysowska, 1962).

Spoiwo o charakterze matrix (tła skalnego) stanowi w arkozie mieszanina węglanu wapnia, serycytu i związków żelaza. Udział spoiwa waha się od $13 \%$ do $25 \%$ objętości skały. Materiał jest zwykle bardzo słabo spojony i obtoczony. Utwory są raczej luźne, łatwo poddają się erozji. Mają zróżnicowane barwy - od białawej przez szarą i różowawą, nawet do ciemnoczerwonej (Fig. 8-10) (Siedlecki, 1952b; Szuwarzyński, 2012).

Otoczaki, które budują wkładki zlepieńców, mają różne pochodzenie i są dobrze obtoczone. Przeważają wśród nich otoczaki kwarcu. Znaleźć można także okazy lidytów, zwietrzałych granitów, granitognejsów, porfirów kwarcowych, gnejsów ortoklazowo-biotytowych, gnejsów oczkowych, gnejsów serycytowo-albitowych, kwarcytów z albitem, piaskowców kwarcytowych, zlepieńców, a rzadziej otoczaków wapieni (Fig. 11) (Pawlikowski, Holcer, 1994). Rozmieszczenie wkładek wykazuje niewielką rozciągłość lateralną. Osiągają one miąższość od kilkunastu do kilkudziesięciu centymetrów (Szuwarzyński, 2012).

Rzadkie i nieregularne wkładki ilaste mają barwę czerwonawą i fioletowawą (Gradziński, 1972). Czasem pojawiają się zielonkawe plamy, co jest wynikiem zachodzących procesów redukcji związków żelaza. Miąższości partii ilastych wahają się od kilku centymetrów do nawet kilkudziesięciu metrów. Czasami tworzą one również formy zwane toczeńcami ilastymi, które osiągają rozmiary do kilkunastu centymetrów średnicy (rzadko powyżej $30 \mathrm{~cm}$ ) (Fig. 12) (Siedlecki, 1952b).

Gruboziarniste partie arkozy kwaczalskiej nie wykazują zbyt wyraźnego i regularnego uławicenia (Fig. 13-14). W miejscach, gdzie daje się je dostrzec, ławice mają od $3 \mathrm{~m}$ do $5 \mathrm{~m}$. Widać w nich warstwowanie krzyżowe, frakcjonalne oraz przekątne o kącie nachylenia do dwudziestu kilku stopni na północ (Pawlikowski, Holcer, 1994). Ta ostatnia cecha pozwoliła na określenie kierunku, z którego transportowany był materiał, jako południowy i południowo-zachodni (Rutkowski, 1972; Gradziński, 1972).

Piaskowce arkozowe powstały w środowisku lądowym. Pory suche przeplatane były porami deszczowymi, w czasie których występowały ulewne deszcze. Słabo wysortowany materiał był wówczas wynoszony z masywu Prakarpat przez okresowe wody o znacznej sile transportu. W okresach suchych złożony na ich przedpolu osad poddawany był głównie działaniu wietrzenia mechanicznego, które przeważało nad chemicznym (Szuwarzyński, 2012). Prowadziło to do przemywania i deflacji, wskutek czego materiał drobny został usunięty, a grubszy utworzył cienką pokrywę (Rutkowski, 1972). Osad ilasty w obrębie arkozy to prawdopodobnie wynik okresowego braku lub znacznego zmniejszenia siły transportowej wody (Rutkowski, 1972).

Specyficznym utworem, który spotkać można w zachodniej odnodze wąwozu Gródek, są zlepieńce rezydualne, bę- dące efektem zachodzących silnych procesów wietrzenia. Zbudowane są głównie z otoczaków kwarcu i arkozy, ale zdarzają się także fragmenty innych skał oraz skrzemieniałego drewna. Materiał jest zwykle słabo obtoczony i wysortowany. Spoiwo stanowi kalcyt, który w wielu miejscach jest grubokrystaliczny, przez co nadaje skale charakterystyczny wygląd (Fig. 15-16) (Słomka i in., 2006).

\section{Wiek arkozy kwaczalskiej}

Wiek arkozy kwaczalskiej określono na stefan (górny karbon). Unikatowość tych osadów wiąże się z ich nieproduktywnością, czyli brakiem pokładów węgla. Wiek ustalono, wykorzystując analogię do arkozy znajdującej się w niecce śródsudeckiej. Diagnoza ta oparta jest na podobnej litologii utworów oraz obecności w nich skrzemieniałych pni kordaitów (wczesnych przedstawicieli roślin szpilkowych).

Utwory arkozowe osiągają zwykle miąższość powyżej $100 \mathrm{~m}$, ale nigdy nie przekraczają $150 \mathrm{~m}$. Leżą zazwyczaj poziomo. Jedynie w centralnej części obszaru występowania (okolice Zagórza) wykazują niewielkie (rzędu 2-5²) nachylenie ku północy i północnemu wschodowi (Siedlecki, 1952b). Ich nadkład stanowią oprócz utworów trzeciorzędu i czwartorzędu także triasowe piaskowce i iłowce (Fig. 17, Tab. 1) (Siedlecki, 1952a; Siedlecki, 1952b).

\section{Skrzemieniałe fragmenty pni drzew}

Skrzemieniałe pnie drzew stanowią właściwie jedyną grupę szczątków organicznych, które zachowały się w osadach arkozowych i są jej typowym elementem (Fig. 18-19). Pnie spotykane w osadach arkozy kwaczalskiej mają mocno zróżnicowane rozmiary, maksymalnie osiągają długość do 7,5 m oraz grubość do 1,2 m (Rutkowski, 1972).

Skrzemieniałe pnie drzew dawniej przypisywano do rodzaju pierwotnych roślin szpilkowych - Araucarites (Rutkowski, 1972), a współcześnie do rodzaju Dadoxylon (D. schrollianum Goeppert, D. rollei Unger, D. saxonicum Goeppert) (Zastawniak, 2001). Termin ten został utworzony w celu opisu skamieniałych fragmentów drewna odkrytego w osadach górnokarbońskich w Szkocji w 1847 roku. Nazwa ta (choć nie jest jedyną obecnie używaną) stosowana jest zwykle w przypadku paleozoicznego skrzemieniałego drewna i odnosi się do konkretnej części rośliny, którą jest pień. Jest on zbudowany z drewna o cewkach oddzielonych od siebie niewielką ilością komórek miękiszu (Reymanówna, 1962; Kotasowa, 1968; Pacyna, 2012).

Termin Dadoxylon wiąże się aktualnie z drewnem kordaitów (kopalnych roślin nagozalążkowych). Klasa Cordaitinae charakteryzowała się smukłym pniem oraz rozłożystą koroną. Liście były sztywne, osadzone spiralnie wokół pnia o szerokim rdzeniu (Kotasowa, 1968). Kordaity osiągały do 50 m wysokości. Natomiast wczesne rośliny iglaste, za które uważa się materiał wyjściowy skamieniałych pni z okolic Chrzanowa, były stosunkowo niewielkich rozmiarów (Pacyna, 2012).

Fragmenty pni zostały zsylifikowane już po sedymentacji osadów i spoczywają w nim in situ (na miejscu) lekko spłaszczone (proporcja osi pionowej do poziomej wynosi 0,8-0,9) w kierunku wschód-zachód (odchylenie około 20-30) (Pawlikowski, Holcer, 1994). 
Obecnie jedyne fragmenty skrzemieniałych pni znajdują się w zwietrzelinie w dnach wąwozów, będącej swoistym wtórnym złożem. Ilość ich jednak systematycznie maleje ze względu na eksploatację przez kolekcjonerów. Występowanie pni w samej arkozie jest rzadkie i maskowane przez zbieraczy.

\section{Ocena stanu zachowania odsłonięć i zagospodarowania wąwozów kwaczalskich}

Obszar występowania arkozy kwaczalskiej w okolicach Chrzanowa wraz z zsylifikowanymi fragmentami pni Dadoxylon nie został dotychczas objęty szczególną ochroną (poza utworzeniem w wąwozie Gródek stanowiska dokumentacyjnego). Powstawały projekty stworzenia rezerwatu obejmującego wąwóz Gródek w Kwaczale (np. Marian Kuc - 1959 r.). Dotyczyły one nie tylko ochrony wychodni piaskowców arkozowych i skrzemieniałych pni, ale także mchów, paproci oraz samej morfologii terenu (Szuwarzyński, 2012).

Wąwozy w Kwaczale mają znaczną wartość naukową i turystyczną. Szczególnie Gródek, który bogaty jest w odsłonięcia arkozy (12 punktów, największe o szerokości 7 m i wysokości 8 m). Wąwóz ten znalazł się na liście 100 obiektów geoturystycznych Polski i w Centralnym Rejestrze Geostanowisk Polski (Szuwarzyński, 2012).

Do niektórych z kwaczalskich wąwozów dostać się można, podążając drogami prowadzącymi bezpośrednio od drogi wojewódzkiej numer 780 biegnącej przez wieś. Ogromnym utrudnieniem jest jednak brak tablic wskazujących kierunek dojścia do poszczególnych wąwozów oraz opisujących ich geomorfologię i geologię. Jedyne źródło informacji to nieprecyzyjna mapa (Fig. 20) oraz tablica - kierunkowskaz.

Zarówno stan zagospodarowania wychodni arkozy w wąwozach w Kwaczale, jak i poziom informacji na temat tych osadów i ich wyjątkowości są bardzo nikłe, a miejscami właściwie nie istnieją. Wskazane byłoby utworzenie kilku tablic informacyjnych o geomorfologii i geologii tego obszaru. Dobrym pomysłem jest również platforma widokowa wzniesiona na jednym ze zboczy wąwozu Gródek. Problemem, z którym należałoby się jednak uporać podczas zagospodarowania, są zsuwy ziemi (Fig. 21). Ponadto warto byłoby zatroszczyć się o samą promocję wspomnianego obszaru, zważywszy na ubogość infrastruktury turystyczno-informacyjnej. Na szczególną uwagę zasługują wąwozy Gródek i Grabowiec. Znacznych rozmiarów wychodnie, które się w nich znajdują są odpowiednie do szerszej ekspozycji. Konieczne jest również wytyczenie ścieżki do samych wąwozów oraz w ich obrębie, z możliwością przedłużenia jako szlaku do wąwozu Simota. Całość mogłaby stanowić świetną ofertę geoturystyczną. Oprócz wspomnianych działań ciekawym pomysłem byłoby także drukowanie i wydawanie własnych broszur informacyjnych, które uzupełniłyby informacje zamieszczone na tablicach.

Chcielibyśmy serdecznie podziękować recenzentom, Panu dr. hab. inż. Markowi Doktorowi oraz Pani dr inż. Ewie Welc za poświęcony czas, wnikliwe oraz trafne uwagi, dzięki którym niniejszy artykut jest czytelny i zrozumiały.

\section{References (Literatura)}

Alexandrowicz S.W., Bogacz K., 1971. Nowe dane o arkozie kwaczalskiej. Wszechświat, 6: 161.

Czerny J., Dudek K., Górniak K., Kwiecińska B., Łodziński M., Manecki A., Matyszkiewicz J., Muszyński M., Parchoniak W., Pawlikowski M., Ratajczak T., Skowroński A., Szydłak T., 2008, Przewodnik do petrografii, Uczelniane Wydawnictwa Naukowo-Dydaktyczne AGH, Kraków, AGH, 240-244 pp.

Dżułyński S., 1956. Przewodnik wycieczki na południowy brzeg Wyżyny Krakowskiej XXVII Zjazdu Polskiego Towarzystwa Geologicznego. Rocznik Polskiego Towarzystwa Geologicznego, 24: 435-448.

Gradziński R., 1972. Przewodnik geologiczny po okolicach Krakowa. Wydawnictwo Geologiczne, Warszawa.

Kondracki J., 2000. Geografia regionalna Polski. PWN, Warszawa.

Kotasowa A., 1968. Flora karbonu produktywnego w północno-wschodniej części Zagłębia Górnośląskiego (rejon dąbrowski), Prace Instytutu Geologicznego, 52: 63-70.

Pacyna G., 2012. Jak rozumieć termin Dadoxylon. Chrzanowskie Zeszyty Muzealne: Araukaryty chrzanowskie, 4: 41-43.

Pawlikowski M., Holcer Z., 1994. Badania mineralogiczne skrzemionkowanych pni i arkozy kwaczalskiej, Archiwum Mineralogiczne, 50: 69-89.

Płonczyński J., Łopusiński L., 1993. Objaśnienia do Szczegółowej Mapy Geologicznej Polski, skala 1 : 50 000, arkusz Krzeszowice (972), Warszawa.

Reymanówna M., 1962. On Dadoxylon schrollianum with Pith and other Dadoxyla from the Upper Carboniferous in South Poland [Dadoxylon schrollianum z rdzeniem i inne Dadoxyla z górnego karbonu Polski południowej]. Acta Palaeobotanica, 3: 3-20.
Rutkowski J., 1972. Osady stefanu Górnośląskiego Zagłębia Węglowego. Przeglad Instytutu Geologicznego, 61: 539-552.

Siedlecka A., Krysowska M., 1962. Badania nad genezą i rozprzestrzenieniem piaskowców karniowickich w północnym obrzeżeniu rowu krzeszowickiego. Rocznik Polskiego Towarzystwa Geologicznego, 32: 371-400.

Siedlecki S., 1952a. Utwory paleozoiczne okolic Krakowa - zagadnienia stratygrafii i tektoniki. Biuletyn Instytutu Geologicznego, 73: 90-110.

Siedlecki S., 1952b. Utwory stefańskie i permskie we wschodniej części Polskiego Zagłębia Węglowego. Acta Geologica Polonica, 2: 300-317.

Siedlecki S., 1956. Przewodnik wycieczki w okolice Krzeszowic i Chrzanowa XXVIII Zjazdu Polskiego Towarzystwa Geologicznego. Rocznik Polskiego Towarzystwa Geologicznego: 24, t. 4, 449-462.

Słomka T., Kicińska-Świderska A., Doktor M., Joniec A., 2006. Katalog obiektów geoturystycznych w Polsce. Akademia Górniczo-Hutnicza, Kraków.

Stille H., 1924. Grundfragen der vergleichenden Tektonik, Berlin.

Stille H., 1928. Die oberkarbonisch-altdyadischen Sedimentationsraume Mittel - Europus in ihrer Abhangigkeit von der wariscischen Tektonik. Congress Heerlen 1927.

Szuwarzyński M., 2012. Araukaryty chrzanowskie z punktu widzenia geologa. Chrzanowskie Zeszyty Muzealne: Araukaryty chrzanowskie, 4: 43-62.

Turnau-Morawska M., Łydka K., 1954. Studia petrograficzne nad arkozą kwaczalską. Rocznik Polskiego Towarzystwa Geologicznego, 22, t. 4: 473-490.

Zastawniak E., 2001. Historia szaty roślinnej Krakowa i jego najbliższych okolic, Wiadomości Botaniczne, 45: 7-14 